\title{
The „7Ps" \&"1G” that rule in the digital world the marketing mix
}

\author{
Luminita PISTOL \\ Spiru Haret University, Bucharest, Romania \\ Rocsana ŢONIŞ (BUCEA-MANEA) \\ Spiru Haret University, Politehnica University, Bucharest, Romania \\ rocsense39@yahoo.com
}

\begin{abstract}
Recently, digital marketing mix is developing very interesting new features, because of the market dynamics, IT fast development, and globalization phenomena. The old paradigm still base on 4 Ps model (product, price, promotion, and place). This research develops a theoretical framework specifically for marketing mix. Starting from a literature review regarding the 4 Ps in marketing and studying the new generation (Z) features, it can be drawn new directions on digital marketing mix, such us people, process, perseverance (other 3P). In the same time the environmental changes urge us to develop and implement new strategies in marketing as to get sustainable eco-innovation. Thus the green marketing (1G) is an important factor in the marketing mix, in raising the awareness on new politics and good practices for protecting the environment. The article brings a new paradigm for marketing mix: $7 P+1 G$, and validate the model by unit root test. A forecast, regarding green marketing, is made with the What-If analysis.
\end{abstract}

Keywords: marketing mix, 7P (product, price, promotion, place, people, process, perseverance) $+1 \mathrm{G}$ (green marketing), cloud computing.

\section{Introduction}

In the era of Internet of Things, the companies face a higher concurrence, due to the viral spread of information and the environmental problems. Thus the companies have to adopt new strategies as to answer the clients' requests and the environmental challenges. The article presents a new approach regarding the online marketing mix with adding a new item with positive impact on sustainable eco-development, green marketing.

The article uses Likert scale to analyze the importance sub-criteria of green marketing. The research methodology stats on $\mathrm{H} 1$ hypothesis: The items of marketing mix have an important impact on sustainable eco-development. The unit root test evaluate how much of the model variables variation are explained. In the end, using What If marketing simulation analysis, a forecast shows that: the increase of awareness level and the business ethics will have an important impact on green marketing (1G).

\section{Literature review}

The literature review talk about the revolution in consumer behavior associated with the new generation, the so-called "Generation $\mathrm{Z}$ or F" or "Facebook". Is the generation that interacts through social media before going of the bed, the generation that is apolitical, that does no trust in politicians, but can change the election results if an online leader convinces them that one policy can affect their interests or economic stability. This generation buys online, divert themselves online and live a second life online through an avatar. This generation seems to have unlimited information and liberty, but they find it difficult to find 
models, and have a leader and seems to be inconsequent in their beliefs and behavior (Jelev, 2015).

The fulminating changes in the technology field, the economic crisis and turmoil worldwide seem to bring the human kind into a dead end. It seems that are no leaders and ideas to save as from self- destruction. The young generation has to get alive, and don't hide anymore behind their avatar. They will change the economic evolution and the marketing features too.

In the marketing field there are well known the 4P: product, price, promotion, and place. In the context of globalization and technological development, in the era of 3.0., we have to add some more „P"s: people, process, perseverance and 1 G: green marketing. We will characterize each of it below:

\section{Product}

In the online environment can be sold three types of products (Gay, 2009):

$\checkmark$ physic products: computer components, books, equipment, medicines, stationery etc.

$\checkmark$ services or intangible products: medical insurance, travel, pay bills, consultancy etc.

$\checkmark$ digitized products:

- Digital composition: software, music, movies, computer games etc;

- It may digitally: airline tickets, books / magazines / newspapers electronics;

- Information as a product: purchased for offline purposes (reports on market research) or presented only for online transmission (white papers), or prepared in response to an on-line request and transmitted using the Internet.

Online service - does not refer to before and after purchase services, but are perceived as part of the promotional effort or improved product. Refers to services which can be paid online and can be delivered off-line (most of them mentioned above) and which can be paid online and can be delivered online. The latest are a function of electronic technology (Watchfire verifying a site on rules of W3C accessibility for users with disabilities) or the result of the service can be transmitted online (results of a SWOT analysis paid to a consulting firm may be sent by email).

Hard to find product, called hidden product, which customers say that he does not know of its existence. Antiquities discs, rare books, works of art were very hard to find before the advent of the Internet and may be purchased especially for customers in the geographical area where the shop is. The Internet has facilitated the rapid expansion of business with this kind of products, competition being very small, making them the most successful businesses, along with big online sellers.

Proofs - Because the online products/services can not be touched, tasted, tested the proofs are vital in the online marketing. The company have to offer the client the possibility to return the product if the client expectations are not met. The company can offer free samples and have to gather as many favorable testimonials as possible. If the clients are happy they will share the information regarding the product. The reverse it is also true: un unhappy client can share the information to thousands of people "in a second".

Pictures/videos - in the online field the first impact is vital, because the product have only 3 to 7 seconds to get consumer attention. The human kind can process images 60,000 times faster than plain text and $90 \%$ of information transmitted to our brain is 
visual. Usually the pictures and videos have a more powerful impact in creating emotional answers. The consumers identify themselves or their expectations with the emotion transmitted through a picture/video (Stone, 2015).

\section{Price}

The online price has to be determined in accordance others 3P: reflecting the cost of the product and its value in consumers' opinion, reflect the distribution and promotion costs and the flexibility to tailor the electronic pricing system. After their organization cover these expenses must reserve a share of the price enabling it to maximize profits, especially when customers are willing to pay a higher price than those intended by the seller. However, in the on-line price must be flexible to change often in the same day, if necessary, such us airlines tickets or investment markets.

Often in the online commodity is cheaper than the physical market due to the reduction of certain personnel costs, storage products, various types of taxes (customs), so the price will be lower and implicitly revenue will be lower. Revenue from affiliate marketing can reunite.

The price level of a product leads to a demand for that product. In theory reducing the price increase demand, and vice versa. This statement should be consistent with price elasticity for different products based on revenue. Price and quantity of goods sold will determine the profit from sale.

Online pricing will take into account the objectives of the company, market segmentation and complexity, customer perception of the value of the product and price, and price competition, raw material suppliers. Prices are determined in relation to the product portfolio with a product lifetime and objectives regarding the sales figures and market share. 2009):

Therefore the price is such that he could achieve the following objectives (Gay,

1. to maintain market area - with long-term potential may determine the choice of higher prices;

2. extra income - can be obtained from aggressive pricing, penetrating, small, shortterm;

3. additional revenue - a market with high competition and customers loyal is intended to maintain prices and increased sales volumes by offering improved products;

4. repositioning - companies change their image and become more attractive for new target market.

Web-marketers can test real-time consumer sensitivity to price changes. At certain price elasticity is high: a decline in prices, but not below a certain limit (the suspicion on product quality and market saturation) can lead to increased sales. Although talking about price transparency on the web, a perfect competition in this environment cannot be achieved because wins the one who moves first, the pricing excessive deception, discrimination prices, product differentiation and access to spaces online market, and so on.

\section{Promotion}

Online promotion can benefit from traditional strategies like specifying the address of company's site in all printed materials, business cards, interviews, documents, publications or any material mentioning the company name in classical promotion campaigns. 
Promotional communications mix includes (Gay, 2009):

- Advertising - using interpersonal communications media.

- Sales promotion - face to face interaction between sellers and prospectors.

- Sales promotion - supplements short-term to stimulate quick sale.

- Public Relations - creating a positive image for the target audience continue.

- Direct marketing - using customer databases for transactional and relational marketing through responses and measurements.

In the online environment, direct marketing get the best response from customers and is performed through Internet promotions, targeted advertising, marketing through search engines and e-mail.

In the online environment personnel involved in promotion it is smaller and consists of specialists to chat in social media by providing information and feedback to customers, free (with media), the professional staff in designing ads online and the specialized online public relations.

\section{Place}

Distribution on the Internet has removed some of the intermediaries that substantially increase the price of products, but appeared other cyber entities that facilitate the distribution of information, such as brokers, web developers implementing shopping cart and those who provide online payment service.

The shopping cart allows customers to buy more products at once, regardless of the level of detail in the online catalog and include secure command forms and trading facilities with the submission secure credit card number.

Online markets respond well to products promoting, payment or purchase online activities. Except digital products distribution, the physical products purchased from the online environment is an issue which is reflected in the cost of the product at a rate of about $10 \%$. Companies can choose to distribute products through distributors consecrated as DHS or to distribute on its own, in which case need a very coherent management system of logistics and execution.

Online distribution requires:

$\checkmark$ establish marketing channels: direct sales - the most effective means for the online environment, sales via cyber intermediaries, sales through online telemarketing, direct sales via e-mail.

$\checkmark$ establish physical distribution: storage, inventory management, transportation, communication, packaging - these operations are easier in the online environment, especially if the transport is done by intermediaries.

$\checkmark$ establishing customer service.

Online market space includes:

a) vertical hubs - based on commercial arrangements with organizations operating in a specific sector: GlobalNetExchange (www.gnx.com)

b) horizontal hubs - places where are sold products or services that are not industryspecific, such as office activity-specific items and MRO (Maintenance, Repair, Operations). Detailed strategies regarding the 4Ps in marketing mix are presented in (Gay, 2009 \& Țoniş 2011). 


\section{People}

People are essential in working with online clients. In online marketing people behind the scene (employees and management) can turn each online meeting into a bill of sale if understanding the client culture. The customer services, professional advices, free tutorials, free information after selling the product can transform a buyer into a loyal customer.

People passion is the one that releases the human creativity and personality. We are all some copies of our families, society individual. It's easier for us to survive under the cover of a generation rules, but what happened if these rules seems to lead us to a dead end? Now is the time that each of us to be unique, the time to feel free of think and feel, to create, to be innovative and to share our experience to others. Yes, we need the support of the society, of the technology, but we have to choose doing the things we like and we have to do it with passion.

People personality is about being yourself, have a unique brand and let the others know the best of you. The online consumer have the nostalgia of the real seller, he wants to know who is selling the product, he expects to get professional advices and he wants to be treated as a unique personality. This is the reason that a virtual company has to open the gates and let the consumer see what happens behind the scene and sometimes engage it in the company community events. The consumers want to know that his opinion counts.

\section{Process}

The online marketing is a continuous evolutionary process, like a spiral. A continuous feedback between clients and company would empower each $\mathrm{P}$ of the marketing mix. Being aware of all new apps, systems and programs the business can have a smooth and consistent evolution. The new online marketing metrics talks about number of loyal and productive relationships built. The statistics regarding the number of clients, or products sold went on the second place.

The make this process fluent the companies have to use technology like datawarehousing and Business Intelligence solution to get instant, in real time a complete relevant panorama of the business, of the key performance indicators, of the clients expectation, of the market resources. The companies have to balance all these, having in mind the internal resources in order to establish the marketing strategy.

But technology became very expensive and with a lot of impediments in implementation and assimilation. Although a new paradigm is the answer to these problems: the Cloud Computing Services. Cloud offer low costs for software and technological resources and services, because the company may choose to pays only for service needed saving time, energy, money and stress. Joining the cloud brings other advantages such as minimal initial costs of implementation (not unbalancing the company cash flow by hiring qualified IT personal for application development), maintenance may be kept remote thus not requiring in-house specialists, provide access to the new technologies in the field, etc.

Cloud computing solutions respond well to the requirements of online companies, as they have less financial and human resources allocated for integration of information technology in their work field, so they have nothing to lose. The cloud solutions enable purchasing services with a small initial investment, without involving in-depth knowledge of IT solutions which is well tailored to online companies. With the widespread deployment of the internet, every enterprise must take into account the presence in the virtual 
environment in which competition has become fierce. Cloud is a form of online advertising, making the company' presence felt online without investing in web design techniques and web-marketing (Ţoniş, 2016).

\section{Perseverance}

A company or product that passes the test of time is a successful one. The results do not always come as fast as expected, but if they materialize in loyal and profitable relationships, then the battle was won.

Future recommendations and creating sustainable products and services is a good way of ensuring loyal customers.

Green marketing is a very efficient marketing technique on long term, representing quality insurance.

Mobile marketing is becoming a pervasive marketing trend that ensures the perseverance in the future strategic approach. "The main concern of mobile marketing has to be targeting the right consumer's with the right message content; otherwise, in time, the consumer's response is much more dramatic compared to the other marketing channels" (Catoiu, 2010).

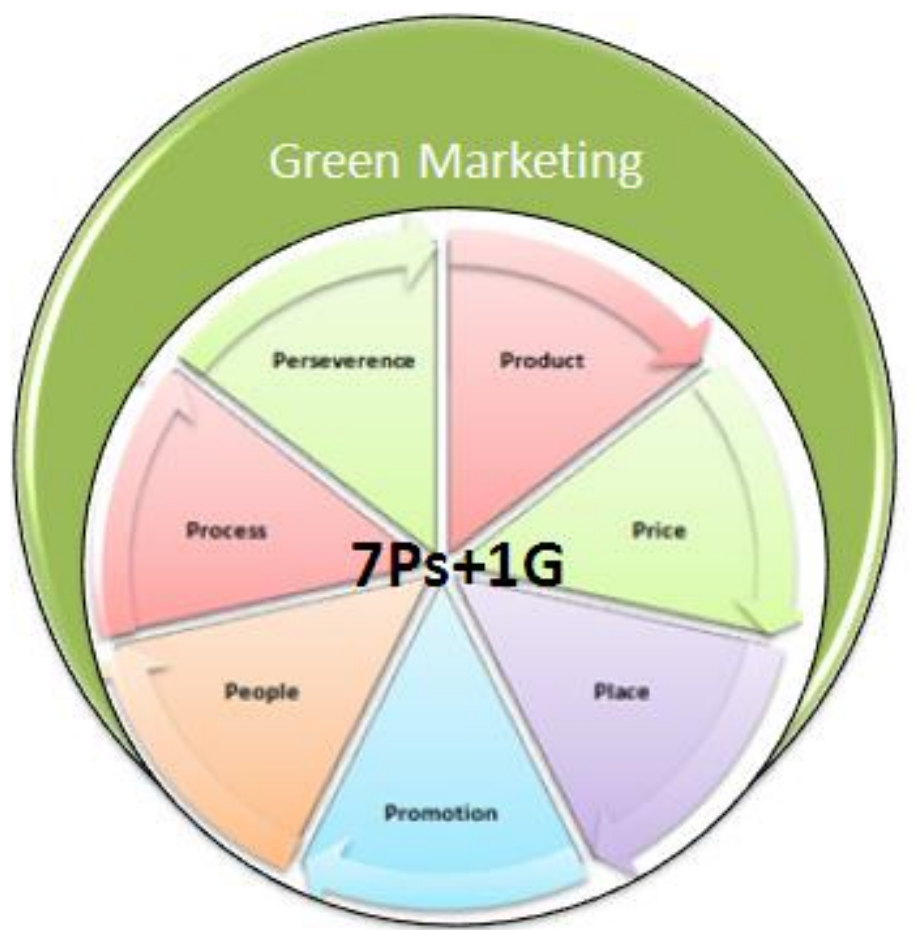

Figure 1. Online Marketing Mix: 7Ps and 1G

Source: Authors' own research results/contribution.

\section{Green Online Marketing}

Green marketing is about designing, pricing, promoting, distributing produces that do not harm the environment. These products may use recyclable resources, green technologies into a sustainable way. It has to avoid global warming, waste of electricity, to use natural resources, solar, wind, wave energy, to reduce soil, noise or air pollution, to recycle water or materials, to reducing $\mathrm{CO} 2$ footprint, to improve recycling of product after use, to replace materials with less polluting or hazardous substitutes, etc. In their attempt to apply the 
principles of green marketing the companies must have more governmental support in reducing or supporting a part of the tariff and quota on the recyclable and biodegradable material that represent the input cost. The government has to organize programs that promote green products for a long term, for the benefit of future generation. In state policies must occupy a special place the education in this respect and determine them to return the packaging when is returnable. (Osman, 2016).

PICBE | 765

To grow a healthy population we should consume organic products. For green products the consumers with higher incomes agree to pay additional tax, as excepting an extra product value. The adoption of non-polluting transportation will reduce the carbon footprint. Online companies can win a corporate image of environmental responsibility if they promote green life style.

Green marketing it is also about promoting the principles and best practices on environmental protection such in Greenpedia.ro portal. The first target should be the parents what have to educate their children in accordance with sustainable eco-behavior. The second target should be the education entities and then the business fields.

Green advertising is a method of sharing and informing the role of the companies regarding the impact with the global issues. Even the government uses green advertising to promote the green environment concept to increase the level of awareness to protect the environment. (Hasan, 2015).

Cloud computing is a very useful method and tool for increasing the online traffic, for reducing the footprint of carbon dioxide and for green innovation. The higher the success of the green innovation and green promotion, the higher is the influence over the firms' performance.

Everybody gets used of the trend of higher price for the eco-products/services. The economical and political entities should support a part of the price for eco-products. Thus these products could have the same price or a lower one then the common products.

In the present the companies that respect the ecological principles are better seen by the consumers, representing quality assurance. They face the challenge to increase the awareness of consumers not only about environmental problems but also about the existence of possible solutions and existence of enviro-label. (Murin, 2105).

Companies can obtain sustainable competitive advantage if integrate the green marketing approach in the business process, including the relation with consumers, employees, investors, suppliers, partners, vendors. One of the biggest benefits of green marketing for the companies is its greater competitive ability, because green products are the guaranty of quality (Nadanyiova, 2015).

The stages of becoming a sustainable greener consumer starts from being an example in the beginning, then becoming a credible partner and offering improvement solutions, developing the market and in the end designing new models of business that can challenge the consumption, as detailed in matrix of green marketing strategy (Majerova, 2015). When the companies put the focus on the social responsibility they benefit of stable future competitive advantages.

\section{Research methodology}

A study on 149 companies (Abdullah, 2016), shows that in the process of adopting green principles, companies confronted 5 types of factors: business ethics, awareness factor, environmental factor, business continuity factor and cost and customer factor. 
These companies consider that respecting the principles of green-manufacturing/ development imply following green technology in the production process, using energy saving machines for manufacturing purpose, always follow green sales promotions, minimizing greenhouse gas emissions and purchase the raw materials from only green suppliers will have an important contribution to eco-sustainable development.

In the first step of research methodology it was implemented a Likert scale on 23 sub-criteria as to find out which is the impact of each factor on sustainable ecodevelopment, as shown in table 1.

Table 1. The impact of each factor on sustainable eco-development

\begin{tabular}{|lrr|}
\hline Criteria & Importance & Percent \\
\hline Product & 0.747203579 & 30.37054 \\
\hline Place & 0.597315436 & 24.27825 \\
\hline People & 0.293064877 & 11.9118 \\
\hline Promotion & 0.261744966 & 10.63878 \\
\hline Process & 0.210290828 & 8.547397 \\
\hline Green & 0.125838926 & 5.114799 \\
\hline Perseverance & 0.124161074 & 5.046602 \\
\hline Price & 0.100671141 & 4.091839 \\
\hline Total & $\mathbf{2 . 4 6 0 2 9 0 8 2 8}$ & \\
\hline
\end{tabular}

Source: Authors' own calculation.

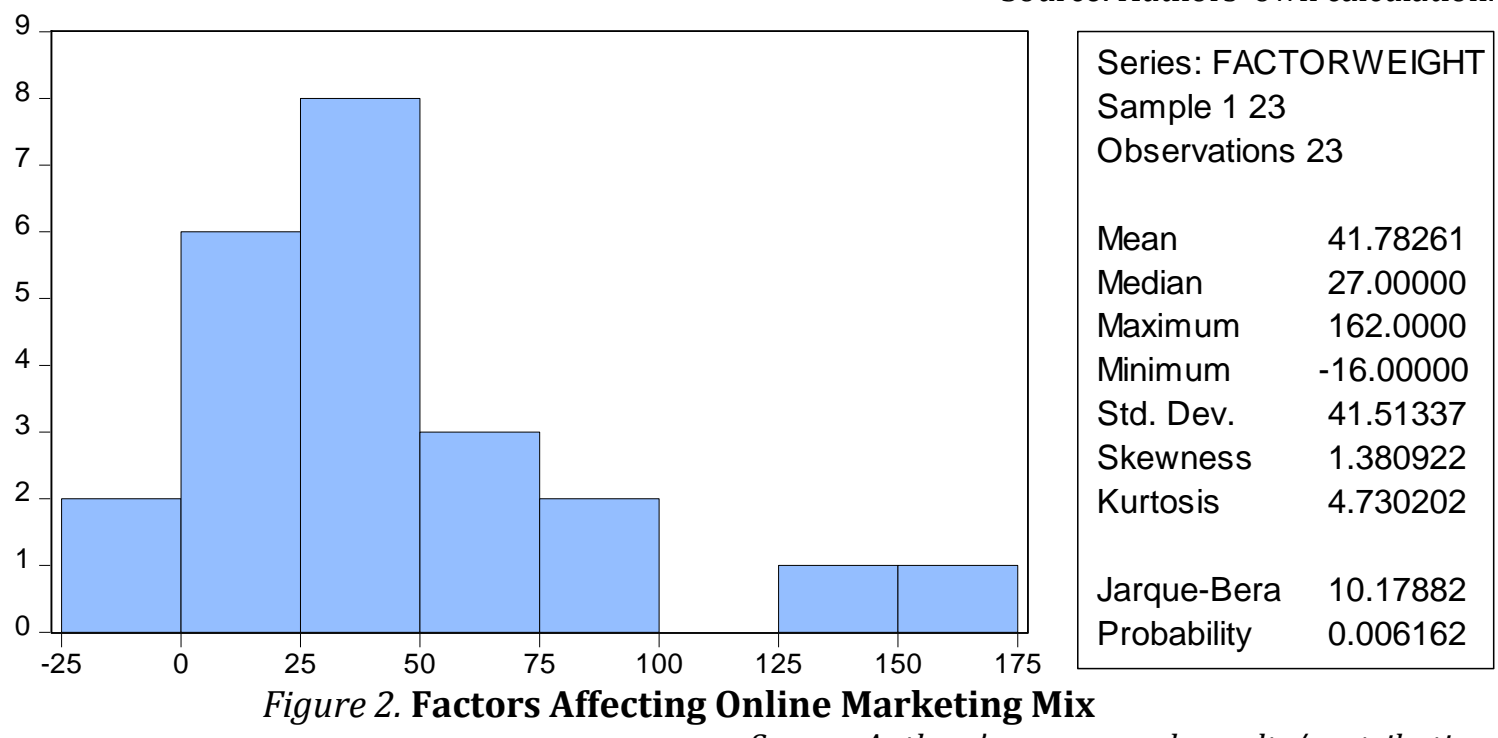

Source: Authors' own research results/contribution.

The histogram above shows that there are factors with higher importance/weight in the on-line marketing mix, such as product, place. There are also factors with medium importance, such as people, promotion and process. The factors that are considered of less importance are green marketing, perseverance and price. The data form a rather sharp curve, with a higher value of Kurtosis (4.73), than the normal, Gauss value 3. The curve shows a left asymmetry, with a Skewness value of 1.38 .

The second step of research methodology has the aim to find out if the data are relevant, and measured the relative quality of the statistical model for the given data. H1 
hypothesis: The items of marketing mix have an important impact on sustainable ecodevelopment.

The Unit Root Test shows that the model is valid, with a probability of $95 \%$, having the $\mathrm{p}$ value $=0.0425<0.05$. This result is based, on Augmented Dickey-Fuller Test, showing that $66 \%$ of data variation is explained by the model (Adjusted R-squared is 0.66 and $\mathrm{p}=0.016<0.05$ ). $\mathrm{R}^{2}$ is 0.71 . If $\mathrm{R}^{2}$ has values closer to the value 1 , the model adjusts better sample data. A very good model has $\mathrm{R}^{2}>0.95$. In our model, it is recommended to add some other variables to be more representative. (Table 2)

Table 2. Unit Root Test - Augmented Dickey-Fuller test

Null Hypothesis: WEIGHT has a unit root

Exogenous: Constant

Lag Length: 0 (Automatic - based on AIC, maxlag=1)

\begin{tabular}{lccc}
\hline \hline & t-Statistic & Prob. $^{*}$ \\
\hline \hline Augmented Dickey-Fuller test statistic & -3.538469 & 0.0425 \\
\hline Test critical values: $\quad$ 1\% level & -4.803492 & \\
& $5 \%$ level & -3.403313 & \\
& 10\% level & -2.841819 & \\
\hline \hline
\end{tabular}

*MacKinnon (1996) one-sided p-values.

Warning: Probabilities and critical values calculated for 20 observations and may not be accurate for a sample size of 7

\begin{tabular}{|c|c|c|c|c|}
\hline Variable & Coefficient & Std. Error & $\mathrm{t}$-Statistic & Prob. \\
\hline WEIGHT(-1) & -1.383158 & 0.390892 & -3.538469 & 0.0166 \\
\hline C & 0.453835 & 0.154007 & 2.946840 & 0.0320 \\
\hline R-squared & 0.714624 & \multicolumn{2}{|c|}{ Mean dependent var } & 0.019415 \\
\hline Adjusted R-squared & 0.657549 & \multicolumn{2}{|c|}{ S.D. dependent var } & 0.420386 \\
\hline S.E. of regression & 0.246007 & \multicolumn{2}{|c|}{ Akaike info criterion } & 0.268043 \\
\hline Sum squared resid & 0.302597 & \multicolumn{2}{|c|}{ Schwarz criterion } & 0.252589 \\
\hline Log likelihood & 1.061850 & \multirow{2}{*}{\multicolumn{2}{|c|}{$\begin{array}{l}\text { Hannan-Quinn criter. } \\
\text { Durbin-Watson stat }\end{array}$}} & 0.077031 \\
\hline F-statistic & 12.52076 & & & 2.303919 \\
\hline Prob(F-statistic) & 0.016590 & & & \\
\hline
\end{tabular}

Source: Authors' own calculation.

For intercept (constant term) H1 hypothesis should be accepted because $\mathrm{p}=0.03$ $<0.05$. With a high probability and an error of 0.15 and the intercept value is 0.45 .

For Weight variable (the importance of each factor in eco-sustainable development) H1 hypothesis should be accepted because $\mathrm{p}=0.016<0.05$. With a high probability and an error of 0.39 the coefficient of Weight is -1.38 . The standard errors are very small, 0.24 .

Durbin-Watson tests the autocorrelation of errors. If the test value is less than 2 there is a positive autocorrelation, if this value is greater than 4 there is a negative autocorrelation. If the test value lies in the interval $[2,4]$ there is no autocorrelation, so the 
model chosen is good and faithfully represent the data series. This is the analyzed case (D$\mathrm{W}=2.3$ ).

Overall the AIC (Augmented Dickey-Fuller test) shows that the model used to measure the impact of each factor on eco-sustainable development fit for the data analyzed, although the model could be more accurate by adding new variables.

Appling What-if marketing simulation analysis an optimistic scenario has been done: the increase of awareness level and the business ethics factor value with $24 \%$ will have a positive impact on sustainable eco-development from 1.26 to 1.73 (maxim of 5 points). The sustainable eco-development can be easy influence, only by adopting the green principles by companies and people all around the world. We all have to change our behavior for a future safety environment, for us and our families (Table 3).

Table 3. Optimistic scenario regarding adopting the green principles by companies and people on sustainable eco-development

\begin{tabular}{lr|r}
\hline Scenario Summary & Current Values: & Increase to: \\
\hline Changing Cells: & & \\
\hline Awareness & 0.261744966 & 0.5 \\
Business Ethics & 0.679194631 & 0.91 \\
\hline Result Cells: & & \\
\hline Sustainable eco-development Impact & 1.265510813 & 1.734571216 \\
\hline
\end{tabular}

Source: Authors' own research.

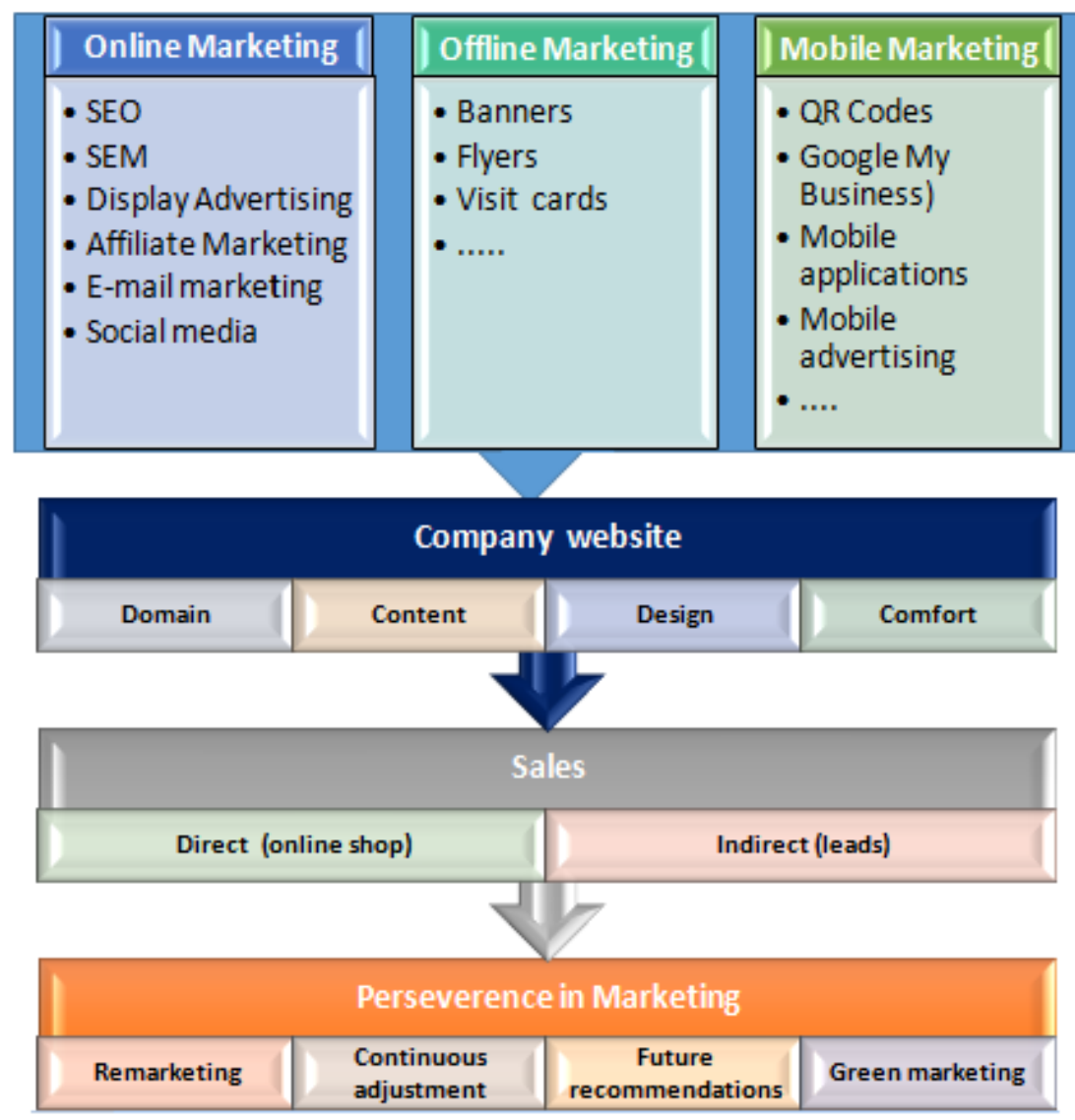

Figure 3. Future Strategic Approach of Online Marketing Mix

Source: Authors' own research results/contribution. 
As to summarize we remember a well-known Chinese proverb that say "A picture is worth a thousand words". It leads us to synthesize the article content into a picture (fig. 2).

\section{Conclusions}

The scientific approach of Marketing Mix starts from the current context facing by the $\mathrm{Z}$ generation. It also analyzes the online marketing mix features. The result of the research is a new conceptual framework regarding online marketing mix that brings new features: more P (people, process, perseverance) and one G (green marketing). These framework is sustained by the model validated by AIC and Durbin-Watson tests. In a future research, we will try to improve the model, by adding new sub-variable. At the end of the paper we present a future strategic approach of online marketing mix.

\section{References}

Abdullah S.S., Meera M.R. \& Abubakkar Siddique M. (2016). Marketing of Green Products and Its Underlying Practices, International Journal of Interdisciplinary Research in Arts and Humanities, 1(1), 157-164.

Cătoiu, I., Gârdan, D., \& Gârdan, P. (2010). Mobile marketing future trends. Annals of "Spiru Haret". Economic Series, 10(1), 11-22. Retrieved from http://anale.spiruharet.ro/index.php/economics/article/view/1011.

Gay R., Charlesworth A., Esen R., (2009). M@rketing on-line: o abordare orientată spre client, Editura All, Bucuresti, 2009 (Traducere după M@rketing on-line: A customerled Approach, Ed. Oxford University press ), ISSN: 978-973-571-754-4.

Hasan Z., Noor Azman A., (2015). The Impact of Green Marketing Strategy on the Firm's Performance in Malaysia, Procedia - Social and Behavioral Sciences, 172, 463-470.

Jelev, V. (2015). The Future of Education into a Digital World. Journal of Economic Development, Environment and People, 4(4), 6-14. Retrieved from http://ojs.spiruharet.ro/index.php/jedep/article/view/119.

Majerova J. (2015). Analysis of Slovak Consumer's Perception of the Green Marketing Activities, Procedia of Economics and Finance, 26, 553-560.

Murin I., Marková I., Zelený I., Jad'ud'ová J. (2015). Green Marketing as a Tool Influencing Consumerś Behavior: Slovak Case Study of Regional Mark Preference, Procedia Economics and Finance, 34, 260-267.

Nadanyiova M., Kicova E., Rypakova M. (2015). Green Marketing and its Exploitation in Slovak Companies, Procedia of Economics and Finance, 26, 219-226.

Osman A., Othman Z.H., Salahudin S.N., Abdullah M.S. (2016). The Awareness and Implementation of Green Concepts in Marketing Mix: A Case of Malaysia, Procedia Economics and Finance, 35, 428-433.

Stone, H.D. (2015). The $10 \mathrm{P}$ 's of Marketing, 24 iun. 2015, available online at https://www.linkedin.com/pulse/10-ps-marketing-helen-denney-stone.

Ţoniş (Bucea-Manea) R, (2016). PHD thesis, Study and Developments on SMEs Support System, Polytechnic University of Bucharest, Faculty of Engineering and Management of Technological Systems.

Ţoniş (Bucea-Manea) R, Bucea-Manea-Tonis R. (2011). WEB MARKETING: Planificarea marketigului online, Editura Fundaţiei România de Mâine, Bucureşti. 